\title{
Loss of neutrophil polarization in colon carcinoma liver metastases of mice with an inducible, liver-specific IGF-I deficiency
}

\author{
Roni F. Rayes ${ }^{1}$, Simon Milette ${ }^{1}$, Maria Celia Fernandez ${ }^{1}$, Boram Ham ${ }^{1}$, Ni Wang ${ }^{1}$, \\ France Bourdeau ${ }^{1}$, Stephanie Perrino ${ }^{1}$, Shoshana Yakar $^{2}$ and Pnina Brodtt ${ }^{1,3,4}$ \\ ${ }^{1}$ Departments of Surgery, McGill University and the McGill University Health Centre, Montréal, QC, Canada \\ ${ }^{2}$ Department of Basic Science and Craniofacial Biology, New York University College of Dentistry, New York, NY, USA \\ ${ }^{3}$ Department of Medicine, McGill University and the McGill University Health Centre, Montréal, QC, Canada \\ ${ }^{4}$ Department of Oncology, McGill University and the McGill University Health Centre, Montréal, QC, Canada \\ Correspondence to: Pnina Brodt, email: pnina.brodt@mcgill.ca \\ Keywords: IGF-l; colorectal carcinoma; liver metastasis; neutrophil polarization; tumor microenvironment \\ Received: August 03, 2017 Accepted: January 19, 2018 Epub: February 28, 2018 Published: March 20, 2018 \\ Copyright: Rayes et al. This is an open-access article distributed under the terms of the Creative Commons Attribution License 3.0 \\ (CC BY 3.0), which permits unrestricted use, distribution, and reproduction in any medium, provided the original author and source \\ are credited.
}

\section{ABSTRACT}

The growth of cancer metastases in the liver depends on a permissive interaction with the hepatic microenvironment and neutrophils can contribute to this interaction, either positively or negatively, depending on their phenotype. Here we investigated the role of IGF-I in the control of the tumor microenvironment in the liver, using mice with a conditional, liver-specific, IGF-I deficiency (iLID) induced by a single tamoxifen injection. In mice that had a sustained ( 3 weeks) IGF-I deficiency prior to the intrasplenic/portal inoculation of colon carcinoma MC-38 cells, we observed an increase in neutrophil accumulation in the liver relative to controls. However, unlike controls, these neutrophils did not acquire the (anti-inflammatory) tumor-promoting phenotype, as evidenced by retention of high ICAM-1 expression and nitric oxide production and low CXCR4, CCL5, and VEGF expression and arginase production, all characteristic of the (pro-inflammatory) phenotype. This coincided with an increase in apoptotic tumor cells and reduced metastasis. Neutrophils isolated from these mice also had reduced IGF-IR expression levels. These changes were not observed in iLID mice with a short-term ( 2 days) IGF-I depletion, despite a $70 \%$ reduction in their circulating IGF-I levels, indicating that a sustained IGF-I deficiency was necessary to alter the neutrophil phenotype. Similar results were obtained with the highly metastatic Lewis lung carcinoma subline $\mathrm{H}-59$ cells and in mice injected with an IGF-Trap that blocks IGF-IR signaling by reducing ligand bioavailability. Our results implicate the IGF axis in neutrophil polarization and the induction of a pro-metastatic microenvironment in the liver.

\section{INTRODUCTION}

The tumor microenvironment is a complex network of immune and non-immune host cells that communicate with each other and with the invading cancer cells through soluble mediators and cell-cell contact to regulate tumor cell growth. A better understanding of the molecular mechanisms underlying this multifaceted communication could lead to better control of tumor progression.
Cells of the innate immune system can promote or inhibit tumor growth, depending on their phenotype. Macrophages and neutrophilic granulocytes (neutrophils) in particular, have an inherent plasticity and their phenotypes can change within a spectrum of activation states in response to chemokines and cytokines in the tumor microenvironment $[1,2]$. Thus, tumor-associated macrophages (TAM) were shown to polarize from a tumoricidal M1 to a tumor-promoting M2 phenotype [3] 
(and reviewed in $[4,5]$ ) and a similar N1-N2 polarization spectrum was demonstrated for neutrophils [6] (and reviewed in $[7,8])$.

The type 1 insulin-like growth factor (IGF-I) axis has been implicated in several aspects of cancer progression (reviewed in [9]). Binding of IGF-I to its cell surface receptor IGF-IR results in receptor autophosphorylation and the activation of downstream effectors of the PI3K/AKT and MAPK signaling pathways that lead to cell growth, proliferation and survival $[10,11]$. IGF-IR overexpression and/or autocrine activation were documented in various human malignancies (reviewed in [9, 12]). The IGF axis has also been implicated in paracrine as well as autocrine regulation of innate and acquired immunity [13]. IGF-IR is expressed on different immune cell types including Tand B-lymphocytes [14], peripheral blood mononuclear cells [15] and NK-cells [16] and these cells are therefore susceptible to regulation by IGF-I. In addition, IGF-IR has been implicated in NF- $\mathrm{B}$-mediated transcriptional regulation of inflammatory cytokines and vascular endothelial cell adhesion receptors, such as intercellular adhesion molecule-1 (ICAM-1) [17]. The IGF axis may therefore play a role in maintenance of immune homeostasis, as well as in the induction of the acute inflammatory response that accompanies the early stages of liver metastasis $[12,18]$. Recently, peripheral blood CD $11 b^{+} \mathrm{GR} 1^{+}$ cells were shown to express high levels of IGF-IR. IGF-IR silencing in these cells resulted in a decrease in the number of circulating neutrophils [19]. Moreover, in a mouse model of liver IGF-I deficiency (LID), congenital loss of IGF-I was associated with a decrease in the number of myeloid derived progenitor cells [20]. Additionally, IGF-IR silencing by a small interfering RNA was shown to induce the production of the pro-inflammatory cytokines TNF- $\alpha$ and INF- $\gamma$ and consequently, alter host immunity in a mouse model of breast cancer [21]. Thus, IGF-I appears to play an active role in the regulation of immune cell function.

The liver is the main source of endocrine IGF-I production. Previously, we have shown that in mice with a congenital liver IGF-I deficiency (LID), the growth of colon carcinoma liver metastases was markedly reduced. [22]. To better understand the effects of liver-derived IGF-I on the growth of hepatic metastases, we used here mice with a conditional, tamoxifen (TX)-inducible liver IGF-I deficiency (the iLID mice), where liver IGF-I depletion can be induced in a temporal manner. Recently we reported that in mice with a prolonged (3 weeks iLID $^{3 \mathrm{~W}}$ ) but not short-term (2 days- iLID ${ }^{2 \mathrm{D}}$ ) liver IGF-I depletion, hepatic stellate cells were not activated in response to tumor cell invasion and could not be rescued from apoptosis in the presence of TNF $\alpha$. In these mice, a significant reduction in the number and size of colon cancer colonies in the liver was also documented [23]. Neutrophils provide a first line of defense against liverinfiltrating tumor cells. We therefore analyzed, here, how a sustained IGF-I depletion affects their recruitment to the liver following tumor cell entry and assessed the role of IGF-I in regulating their state of polarization.

\section{RESULTS}

\section{A sustained reduction in liver IGF-I production alters neutrophil recruitment into the liver in response to metastatic cancer cells}

The entry of metastatic cancer cells into the liver initiates an inflammatory cascade that leads to the recruitment and activation of innate immune response cells. Previously we have shown that in mice with a sustained liver IGF-I deficiency, induced in iLID mice by a TX injection, 3 weeks prior to the intraspelnic/portal injection of colon carcinoma MC-38 cells, liver colonization was reduced. An impaired hepatic stellate cell activation was also documented in these mice [23]. To begin to elucidate the effect of a long-term reduction in circulating IGF-I levels on the immune microenvironment of metastatic cells in the liver, we first measured the expression of a range of inflammatory/immune response indicators such as chemokines, cytokines and vascular cell adhesion molecules in the livers of iLID mice injected with GFP-tagged MC-38 cells, 1-6 days earlier. In mice with a short-term (2 days, ILID $^{2 \mathrm{D}}$ ) or sustained (3 weeks, ILID ${ }^{3 \mathrm{~W}}$ ) IGF-I depletion, a marked reduction (up to $90 \%$ ) in circulating IGF-I levels, as compared to control mice was seen (Supplementary Table 1 and Figure 1). In all mice, we observed an increase in CXCL-1 expression levels within $24 \mathrm{hr}$ of tumor injection and this persisted for at least 6 days (Figure 1A, 1B). However, while in livers of control (vehicle-treated) mice or $\mathrm{iLID}^{2 \mathrm{D}}$ mice -(Figure 1B), these increases ranged from 1.5 - 5-fold relative to normal (tumor-free) controls, the increase in $\mathrm{iLID}^{3 \mathrm{~W}}$ was of a greater magnitude and was as high as 20-fold relative to the respective controls, 3 days post tumor cell inoculation (Figure 1A). Differences were also observed in VEGF expression levels in these mice. Namely, while in control, vehicle-treated and iLID $^{2 \mathrm{D}}$ mice an increase in VEGF mRNA relative to normal levels was evident by 6 days post tumor injection (Figure 1D), these levels did not change in iLID $^{3 \mathrm{~W}}$ mice and were $\sim 3$-fold lower than in their respective, vehicle-treated controls (Figure 1C). mRNA expression levels for other inflammatory indicators including IL-1 $\beta$, IL-18, CXCL-2, E-selectin, P-selectin, VCAM-1 and ICAM-1 did not significantly differ in $\mathrm{iLID}^{3 \mathrm{~W}}, \mathrm{iLID}^{2 \mathrm{D}}$ and the respective control mice (Supplementary Figure 2).

\section{Increased accumulation of $\mathrm{Ly}^{6} \mathrm{G}^{+}$cells in iLID mice with a sustained IGF-I deficiency}

The marked increased in CXCL-1 expression was indicative of a change in the immune microenvironment of the livers in $\mathrm{iLID}^{3 \mathrm{~W}}$ mice. To identify changes in the composition of the innate immune cell infiltrate that were 
associated with hepatic metastases in these mice, IHC was performed on frozen liver sections derived from tumor-injected mice, 3 and 6 days post tumor injection. Consistent with our observation of increased CXCL1 expression levels, we observed on day 6 , a $\sim 4$-fold increase in the accumulation of $\mathrm{Ly}_{6 \mathrm{G}}{ }^{+}$cells, as compared to controls, in areas of the liver infiltrated by tumor cells (Figure 2A) and this was not observed in iLID $^{2 \mathrm{D}}$ mice (Figure 2B). Concomitant with this increase, we found in these mice $\mathrm{a} \sim 2$-fold increase in the proportion of apoptotic $\mathrm{MC}-38-\mathrm{GFP}^{+}$cells, as determined by cleaved caspase 3 levels detectable by IHC (Figure 2C) and this was also not observed in the iLID $^{2 \mathrm{D}}$ mice (Figure 2D). The reason for the slight increase in apoptosis in control (vehicletreated) $\mathrm{iLID}^{3 \mathrm{~W}}$ mice, relative to control $\mathrm{iLID}^{2 \mathrm{D}}$ mice $(p>$ 0.05 ) is not presently clear and may have been due to the difference in the age of these mice $\left(\mathrm{iLID}^{3 \mathrm{~W}}\right.$ mice were at least 3 weeks older) [24]. Interestingly, the total number

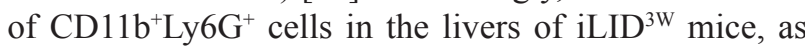
determined by flow cytometry, was not significantly altered (Supplementary Figure 3), indicating a selective enrichment of these cells in the tumor microenvironment.
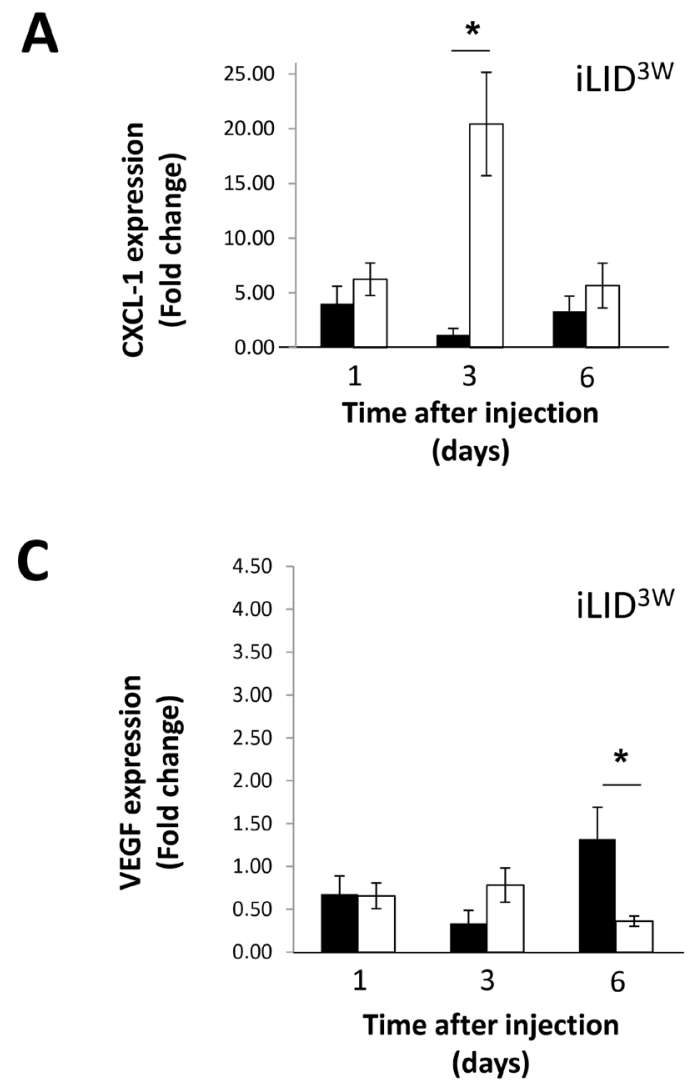

\section{Neutrophils in mice with a sustained IGF-I depletion do not polarize to the (tumor promoting) phenotype}

To better characterize the population of neutrophils that accumulated in the livers of tumor bearing mice, $\mathrm{CD}_{11 \mathrm{~b}} \mathrm{Ly}_{6 \mathrm{G}}{ }^{+}$cells were isolated using fluorescenceactivated cell sorting, RNA was extracted and the expression of pro-inflammatory neutrophil markers [8] was analyzed by qPCR. When $\mathrm{CD} 11 \mathrm{~b}^{+} \mathrm{Ly}_{6 \mathrm{G}}^{+}$cells isolated from livers of MC-38 - inoculated $\mathrm{iLID}^{3 \mathrm{~W}}$ mice were analyzed, we found that their ICAM-1 expression levels were 3-fold higher, while their CCL5 and VEGF expression levels were 4.5 and $\sim 2$-fold lower, respectively, than in the same cells isolated from the control mice (Figure 3A). This indicated that in the $\mathrm{iLID}^{3 \mathrm{~W}}$ mice, in contrast to controls, tumor associated neutrophils (TAN) did not lose the expression of markers characteristic of the pro-inflammatory (N1) phenotype (high ICAM-1 and low CCL5 and VEGF expression [8]). These phenotypic differences were not observed in $\mathrm{CD} 11 \mathrm{~b}^{+} \mathrm{Ly}_{6 \mathrm{G}} \mathrm{G}^{+}$cells isolated from $\mathrm{iLID}^{2 \mathrm{D}}$ mice where, in fact, a trend $(p>0.05)$

B

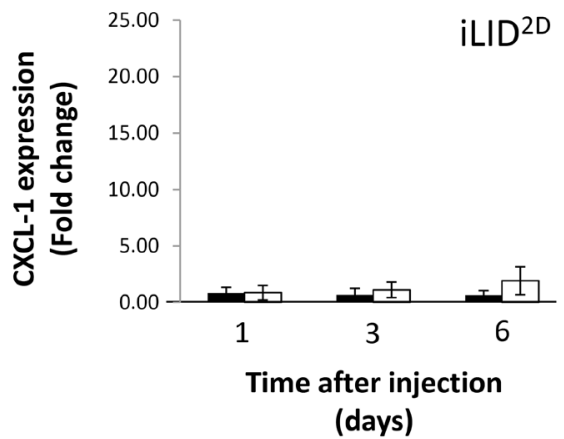

D

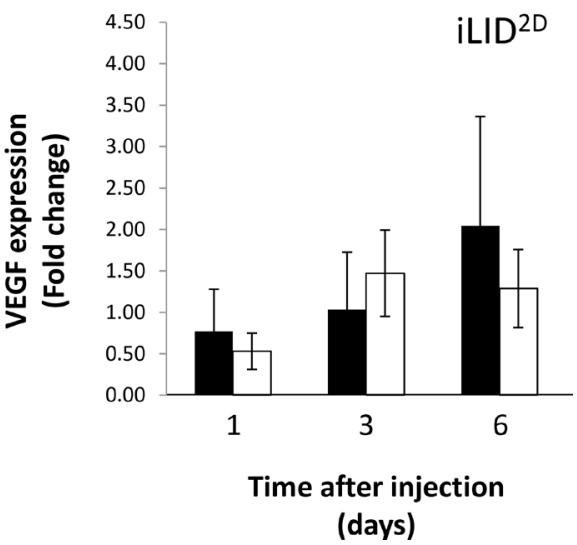

Figure 1: Altered chemokine/cytokine expression in tumor-injected mice with a sustained IGF-I deficiency. iLID mice were injected i.p. with TX or sunflower seed oil (vehicle) 3 weeks $(\mathbf{A}, \mathbf{C})$ or 2 days $(\mathbf{B}, \mathbf{D})$ prior to the injection of $2.5 \times 10^{5} \mathrm{MC}-38$-GFP cells via the intrasplenic/portal route. Mice were sacrificed 1, 3 or 6 days post tumor injection and liver fragments used for RNA extraction and analysis. Shown are expression levels of CXCL-1 (A, B) and VEGF (C, D) in TX- (white bar) and vehicle- (black bar)-injected mice, each normalized to GAPDH. The data are expressed as fold change $( \pm \mathrm{SE})$ relative to non-injected mice that were assigned a value of 1 . They are based on 3 mice per group per time point; ${ }^{*} p<0.05$. 
toward increased CCL5 and VEGF and decreased ICAM-1 expression levels relative to the controls was observed (Figure 3B), consistent with increased polarization of these cells to a tumor-promoting (N2) phenotype (Figure 3B). The variability in the expression levels seen in the latter cells may reflect the spectrum of polarization states characteristic of tumor-associated inflammatory cells [6], and this, in turn, may be affected by the proximity of the neutrophils to the metastases. The difference between neutrophils isolated from $\mathrm{iLID}^{3 \mathrm{~W}}$ and $\mathrm{iLID}^{2 \mathrm{D}}$ mice was confirmed functionally, when arginase activity levels in these cells were measured, revealing that neutrophils isolated from iLID $^{3 \mathrm{~W}}$ mice had a 3-fold reduction in this activity (Figure 3C), while their nitric oxide level was 3-fold higher (Figure 3D) than in the controls. This suggested that iLID $^{3 \mathrm{~W}}$ neutrophils did not acquire the functional properties of tumor-promoting
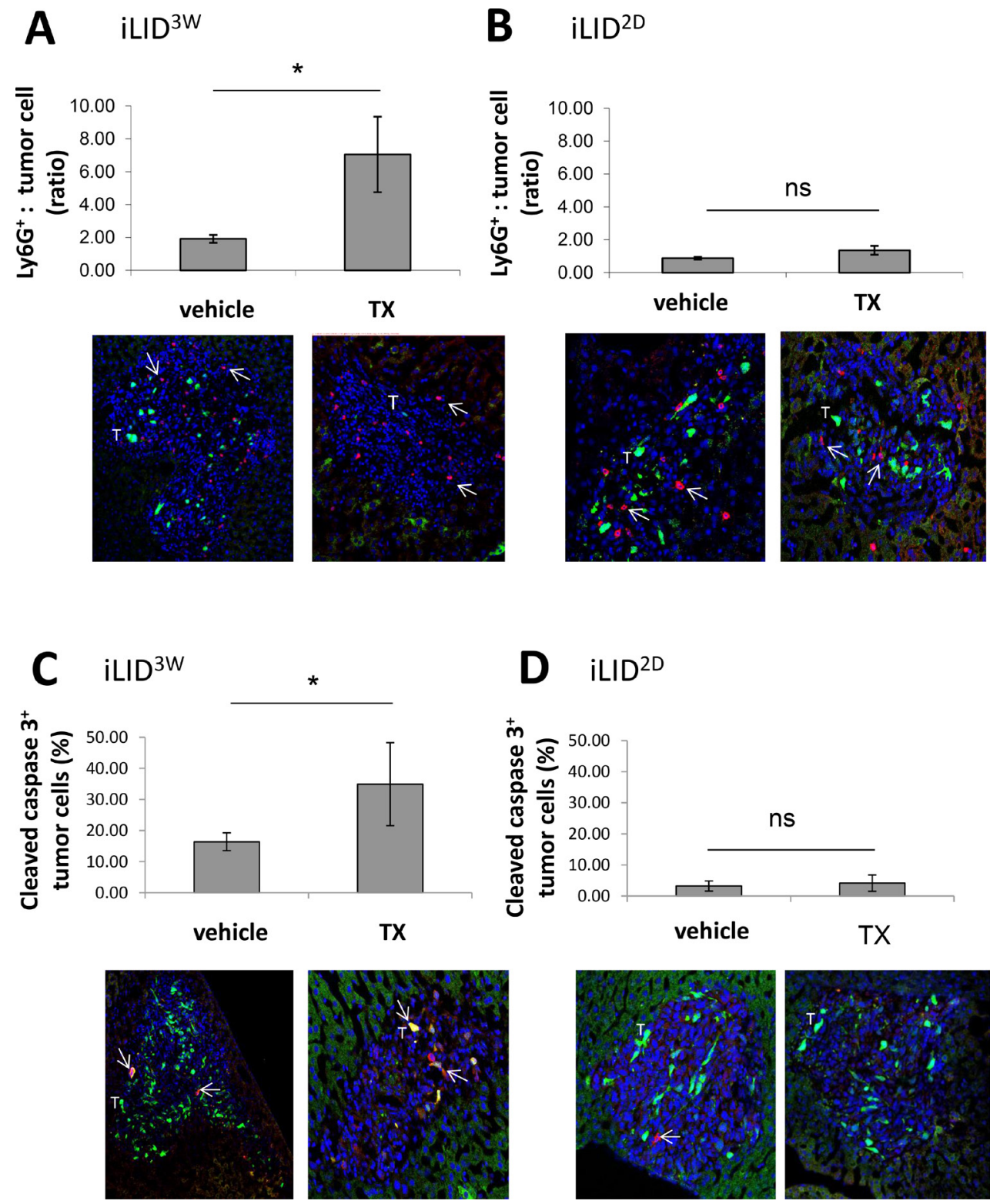

2: Increased neutrophil accumulation and tumor cell apoptosis in IGF-I deficient mice. iLID mice were injected i.p. with TX or vehicle, 3 weeks $(\mathbf{A}, \mathbf{C})$ or 2 days $(\mathbf{B}, \mathbf{D})$ prior to the injection of $2.5 \times 10^{5} \mathrm{MC}-38$-GFP cells via the intrasplenic/portal route. Mice were sacrificed 6 days post tumor injection and livers first perfused with PFA and then excised for subsequent immunohistochemical analysis. Shown in the bar graphs $(\mathrm{A}, \mathrm{B})$ are the mean numbers $( \pm \mathrm{SE})$ of $\mathrm{Ly}_{6 \mathrm{G}}{ }^{+}$cells counted in tumor infiltrated areas of the liver (top). They are based on 12 random fields $(\times 10$ objective $)$, counted per condition and expressed as a ratio to the number of GFP ${ }^{+}$MC- 38 cells $^{2}$ in each field. Representative images are shown on the bottom with DAPI in blue, GFP ${ }^{+} \mathrm{MC}-38$ cells (T) in green and Ly6G ${ }^{+}$cells in red (arrows). Shown in (C, D) are results of quantification of MC-38 cells that expressed cleaved caspase 3, counted in 15 random fields $(\times 10$ objective) per condition and expressed as $\%( \pm \mathrm{SE})$ of the total number of tumor cells per field. Representative images are shown at the bottom with DAPI in blue, GFP ${ }^{+} \mathrm{MC}-38$ cells $(\mathrm{T})$ in green and cleaved caspase 3-positive cells in red (arrow). $n=3$. ns $=$ not significant, ${ }^{*} p<0.05$. 
neutrophils. Consistent with these results, an IHC analysis of $\mathrm{Ly} 6 \mathrm{G}^{+}$cells in liver cryostat sections derived from tumor-inoculated mice showed that approximately $20 \%$ of the neutrophils in tumor-infiltrated areas in control mice expressed the $\mathrm{N} 2$ marker CXCR4, as compared to only $5 \%$ in $\mathrm{iLID}^{3 \mathrm{~W}}$ mice (Figure $3 \mathrm{E}$ ). A similar difference in the phenotype of $\mathrm{CD} 11 \mathrm{~b}^{+} \mathrm{Ly}_{6 \mathrm{G}} \mathrm{G}^{+}$neutrophils was also observed following the injection of highly metastatic lung carcinoma H-59 cells into iLID ${ }^{3 \mathrm{~W}}$ mice. These neutrophils expressed a 2.2-fold higher ICAM-1 level $(p<0.005)$ and a 1.7 -fold lower VEGF-A level $(p=0.11)$ relative to neutrophils of control, wild type mice injected with TX (Figure 3F). Moreover, similarly to our findings in mice injected with colon carcinoma MC-38 cells ([23] and see also here Supplementary Figure 4), these mice also had reduced numbers of liver metastases, as compared to the controls (Figure 3G). Together, these results indicated that in mice with a sustained liver IGF-I depletion, the ability of

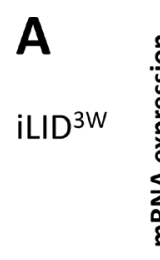

\section{B $\mathrm{B}$}
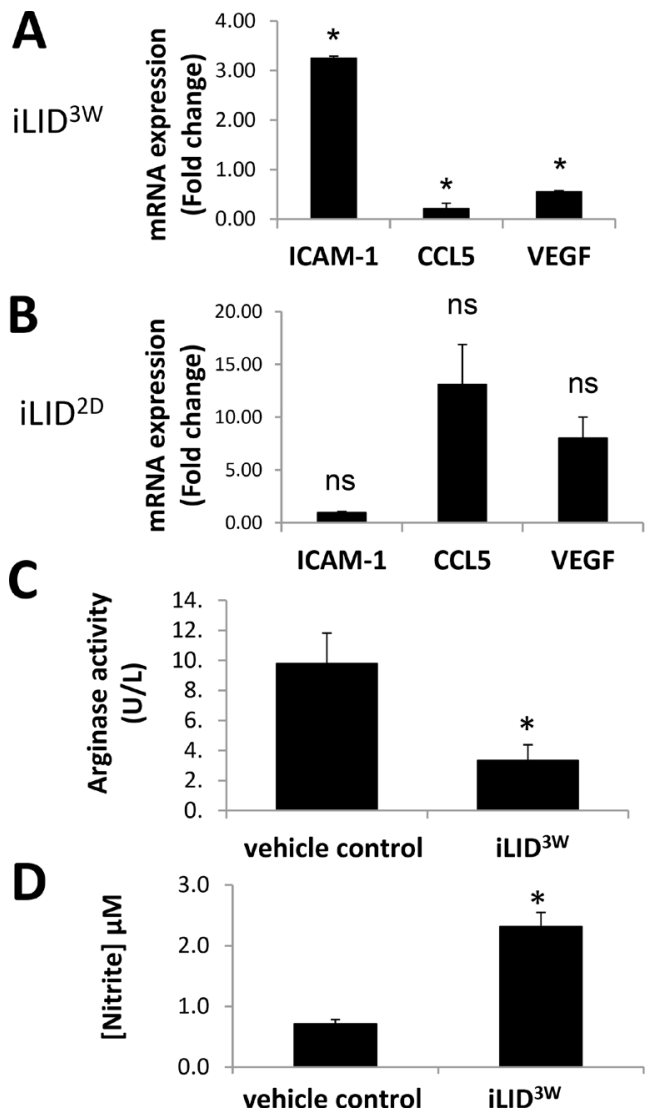

$\mathbf{E}$

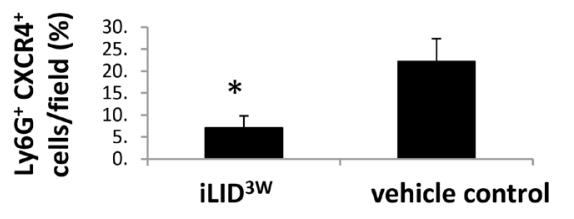

$\mathbf{F}$
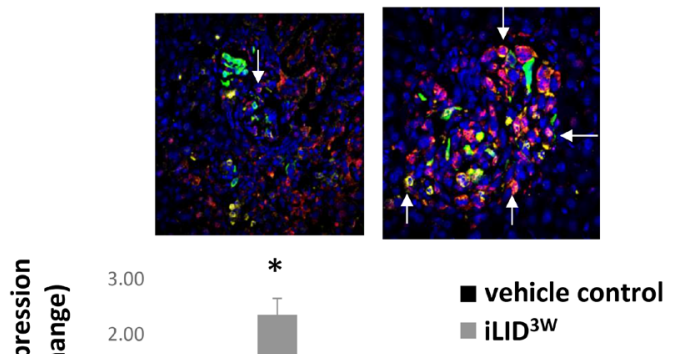

$\mathbf{G}$

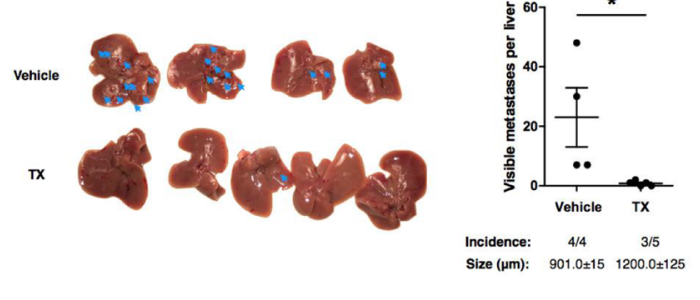

Figure 3: Reduced neutrophil polarization in mice with a sustained IGF-I deficiency. Mice were injected as described in the legend to Figure 2 and sacrificed 6 days later. (A-E). Immune cells were collected and CD11 $\mathrm{b}^{+} \mathrm{Ly}_{6 \mathrm{G}^{+}}$cells isolated using FACS sorting. Shown in (A) and (B) are results of qPCR performed on RNA extracted from CD11b $\mathrm{Ly}^{+} \mathrm{G}^{+}$cells isolated from iLID $^{3 \mathrm{~W}}(\mathrm{~A})$ or $\mathrm{iLID}^{2 \mathrm{D}}(\mathrm{B})$ mice. They are based on 3 separate experiments (7-10 mice per group per experiment) and normalized to GAPDH and expressed as a ratio to the respective vehicle treated control mice. Shown in (C) are results of the arginase assay performed on total lysates of isolated $\mathrm{CD}_{11} \mathrm{~b}^{+} \mathrm{Ly}_{6 \mathrm{G}}{ }^{+}$cells. They are based on 3 separate experiments (7-10 mice per group per experiment) and expressed as means ( $\left.\pm \mathrm{SE}\right)$. Shown in (D) are nitrate levels measured in conditioned media of CD11 $\mathrm{b}^{+} \mathrm{Ly} 6 \mathrm{G}^{+}$cells isolated from the indicated mice and incubated at $37^{\circ} \mathrm{C}$ overnight. They are based on 3 separate experiments (7-10 mice per group per experiment) and expressed as means ( \pm SE). Shown in (E) are results of immunohistochemistry performed on cryostat sections derived from MC-38 cells-injected mice. Representative images of double stained cells (white arrow) with antibodies to Ly6G (in yellow) and CXCR4 (in red) around tumor cells (green) are shown on the bottom with DAPI (in blue). Results in the bar graph (top) are based on quantification performed on 8-10 sections for 3 different mice per group $(n=3$ mice $)$ and expressed as percent $( \pm \mathrm{SE})$ of $\mathrm{Ly} 6 \mathrm{G}^{+}$cells that also stained positively for CXCR $4^{+}$. (F) iLID mice were injected i.p. with TX or vehicle, 3 weeks prior to the injection of $2.5 \times 10^{5} \mathrm{MC}-38$ cells via the intrasplenic/portal route. Mice were sacrificed 6 days post tumor injection and hepatic immune cells isolated. $\mathrm{CD} 11 \mathrm{~b}^{+} \mathrm{Ly}_{6 \mathrm{G}} \mathrm{G}^{+}$cells were sorted by FACS and RNA extracted for RT-qPCR analysis. Data in the bar graph are expressed as mean fold change $( \pm \mathrm{SE})$ relative to vehicle control, based on 3 separate experiments $(5-7$ mice per group). (G) iLID mice received a single i.p. injection of $0.3 \mathrm{mg}$ TX or sunflower seed oil (vehicle) 3 weeks prior to the injection of $10^{5}$ $\mathrm{H}-59$ cells via the intrasplenic/portal route. Mice were sacrificed 14 days following tumor cell injection and metastases on the surfaces of the livers enumerated. Shown in the graph are the numbers of metastases seen on the individual livers in each group. Horizontal bars denote medians. The number of mice in each group that developed hepatic metastases is indicated on the bottom of each column. The average size of the metastases $( \pm \mathrm{SD})$ is shown below each column. $n=4-5$; ns $=$ not significant, ${ }^{*} p<0.05$. Representative livers from each group are shown on the left. Metastases are indicated by arrows. 
neutrophils to polarize to a tumor-promoting phenotype was impaired and this effect was not tumor specific.

Of note, we have observed that MC-38 and H-59 cells were insensitive to stimulation by estrogen (data not shown). This, and the data shown in Figures $3 \mathrm{~F}$ and Supplementary Figure 4 suggest that TX injections did not have a direct effect on the tumor cells in vivo. However, we cannot entirely rule out the possibility that within 2 days of injection, TX metabolites had indirect effects on the tumor microenvironment.

\section{IGF-IR expression is markedly reduced in CD11 b $^{+}{\text {Ly } 6 G^{+}}^{+}$cells isolated from iLID $^{3 \mathrm{~W}}$ mice}

The finding that neutrophils from iLID $^{3 \mathrm{~W}}$ mice were phenotypically distinct from those exposed to reduced IGF-I levels for only 2 days prompted us to ask whether this may be due to differences in their IGF-IR expression levels. IGF-IR expression levels on $\mathrm{CD}_{11} \mathrm{~b}^{+} \mathrm{Ly}_{6 \mathrm{G}}{ }^{+}$cells isolated from these mice were analyzed by qPCR and flow cytometry. In neutrophils isolated from iLID ${ }^{3 \mathrm{~W}}$ mice, we found a $\sim 5$-fold decrease in IGF-IR mRNA and a $\sim 2$-fold decrease in IGF-IR protein levels, as compared to controls (Figure 4A), and this was not observed in neutrophils from iLID $^{2 \mathrm{D}}$ mice (Figure 4B). In comparison to the latter, IGFIR expression levels on neutrophils from iLID ${ }^{3 \mathrm{~W}}$ mice were reduced by $>65 \%$.

\section{IGF-I can directly induce changes in the neutrophil phenotype}

The above results implicated IGF-I and the IGF-IR in neutrophil polarization. To determine whether IGF-I could directly induce the phenotypic changes associated with the N1-N2 transition, CD11b ${ }^{+} \mathrm{Ly}_{6 \mathrm{G}^{+}}$cells were isolated from mouse bone marrow and stimulated in vitro with $10 \mathrm{ng} / \mathrm{ml} \mathrm{IGF-I} \mathrm{for} \mathrm{3-4} \mathrm{hours,} \mathrm{prior} \mathrm{to} \mathrm{RNA}$ extraction for analysis by qPCR or for 6-8 hours prior to cell lysis for protein analysis by Western blotting or ELISA. We observed a small ( $\sim 1.3$-fold) but reproducible $(p<0.05)$ increase in IGF-IR phosphorylation following IGF-I stimulation for 10 minutes (Figure 5A). This was followed 3-4 hr later by a 4.5-fold increase in CCL5 and VEGF expression levels (Figure 5B) and a corresponding 2-fold increase in CCL5 and VEGF protein production levels, as measured 3-4 hr later (Figure 5C and 5D). These results showed that IGF-I could directly activate the production of $\mathrm{N} 2$-associated proteins in the isolated neutrophils. In addition, we also observed in IGF-I -stimulated neutrophils a $\sim 2$-fold increase in the expression of TGF- $\beta 1$ (Figure 5B) - a growth factor previously implicated in neutrophil polarization. Because most antibodies to phospho-IGF-IR also recognize the activated form of the insulin receptor (IR), we cannot entirely rule out the possibility that the IR was also activated in these

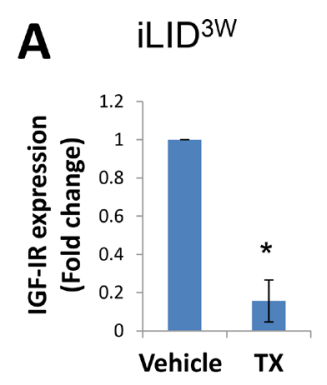

B iLID $2 \mathrm{D}$

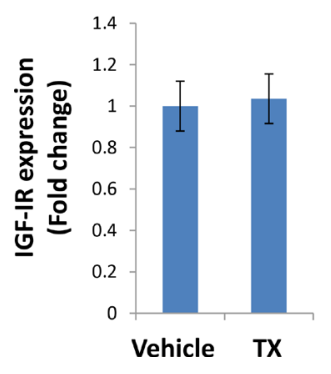

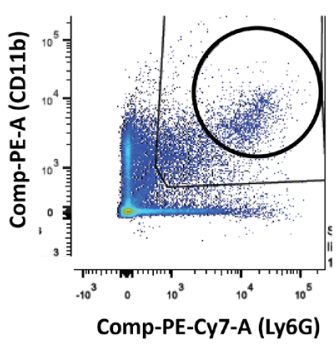

Comp-PE-Cy7-A (Ly6G)

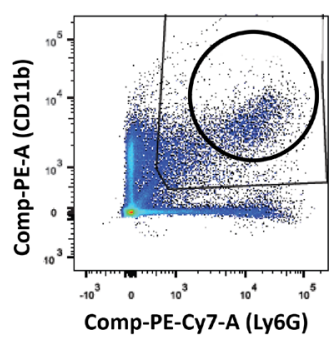

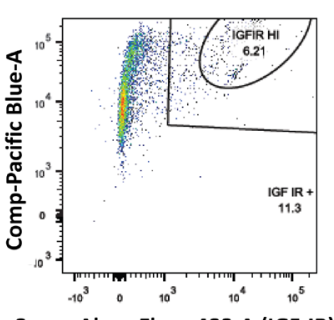

Comp-Alexa Fluor 488-A (IGF-IR)
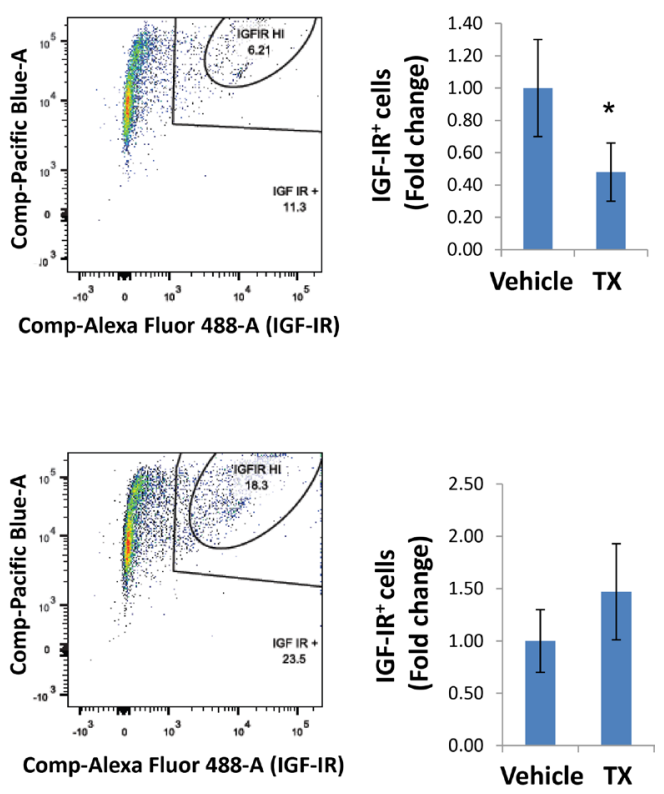

Figure 4: A sustained IGF-I depletion reduces IGF-IR expression levels in neutrophils. ILID mice were injected with TX or vehicle 3 weeks $(\mathbf{A})$ or 2 days $(\mathbf{B})$ prior to the injection of $5 \times 10^{4} \mathrm{MC}-38$ cells via the intrasplenic/portal route. Mice were sacrificed 6 days later and $\mathrm{CD} 11 \mathrm{~b}^{+} \mathrm{Ly} 6 \mathrm{G}^{+}$cells isolated and processed for qPCR (left) or flow cytometry (middle and right panels) using an anti IGFIR antibody (diluted 1:100) and an Alexa Fluor 488 secondary antibody (diluted 1:200) for the latter. Shown are IGF-IR mRNA levels normalized to GAPDH (left panels), flow cytometry profiles (middle panels) and the percent IGF-IR ${ }^{+}$neutrophils (right panels) expressed as means $( \pm \mathrm{SE})$ of three experiments per condition (and 3 mice per experiment) relative to the respective, vehicle-injected mice that were assigned a value of $1 . \mathrm{ns}=$ not significant, ${ }^{*} p<0.05$. 
cells. However, given the 100-fold lower affinity of IGF-I for IR (as compared to IGF-IR) [25], the transcriptional activation of CCL5 and VEGF in these neutrophils was most likely mediated downstream of IGF-IR.

Finally, when mice inoculated with MC-38 cells were treated with 1 or $10 \mathrm{mg} / \mathrm{kg}$ of the IGF-TRAP-an inhibitor of IGF-IR signaling- [26] and their neutrophils isolated for analysis 6 days later, we found a significant and dose dependent increase in their ICAM-1:CXCR4 ratios, as assessed by flow cytometry (Figure 6A, 6B), indicating that the phenotype of TAN can be altered in vivo by targeting the IGF signaling axis.

\section{DISCUSSION}

IGF-I can act directly on tumor cells to regulate their proliferation, survival, invasion, and metastasis (reviewed in $[12,27]$ ). In addition, the IGF-axis can also affect tumor growth indirectly by modulating the host immune response (reviewed in [28]), rendering the microenvironment more, or less, permissive to cancer growth. IGF-IR targeting for cancer treatment has entered the clinical realm [26, 29-34]. An understanding of the multifaceted role that the IGF-axis plays in cancer development is important for the design of IGF-targeting regimens and the evaluation of their impact. Here, we used mice with an inducible liver IGF-I deficiency to elucidate the role of IGF-I in experimental liver metastasis of colon and lung carcinoma cells, in particular its contribution to the host innate immune response engendered by the metastatic tumor cells.

Our data show that in a microenvironment subjected to a sustained reduction in circulating IGF-I levels, neutrophil polarization to a tumor-promoting (N2) phenotype was diminished and this was associated with a decrease in liver metastases formation in 2 different tumor models of metastasis. Taken together, our results identify the IGF-I receptor as a promoter of neutrophil
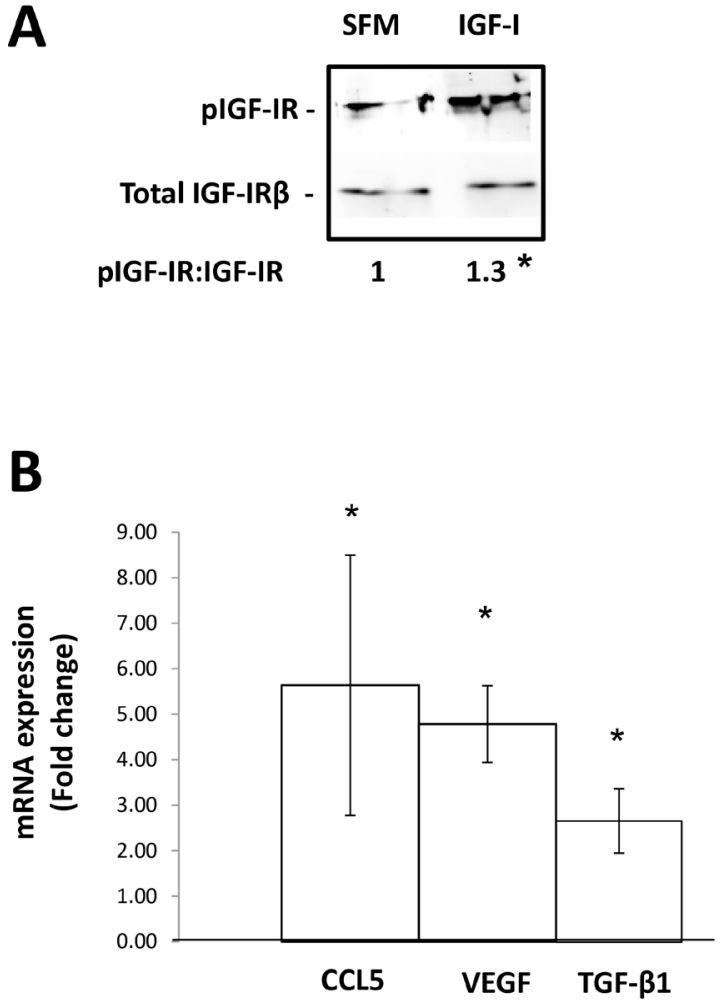
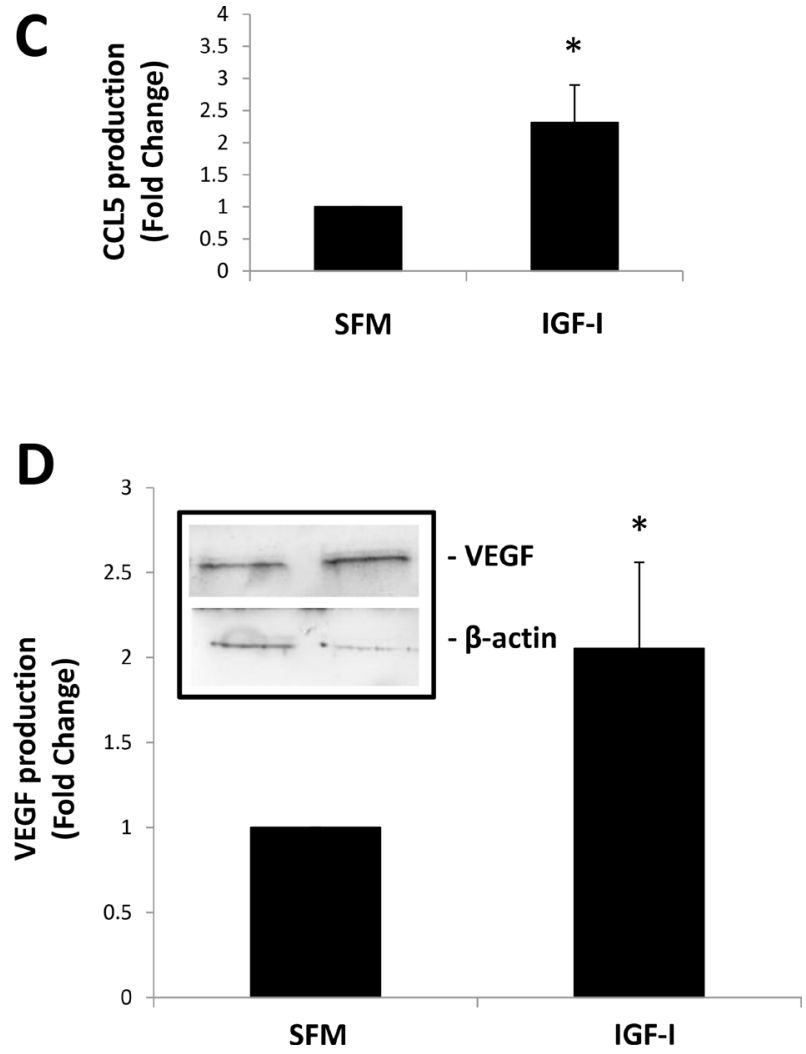

Figure 5: IGF-I can directly induce the expression of mRNA transcripts that define the tumor-promoting phenotype of neutrophils. CD $11 \mathrm{~b}^{+} \mathrm{Ly} 6 \mathrm{G}^{+}$cells were isolate from the bone marrow of C57BL/6 mice using FACS sorting and cultured in vitro in serum free media (SFM) containing (or not) $10 \mathrm{ng} / \mathrm{ml} \mathrm{IGF-I} \mathrm{for} \mathrm{either} 5$ minutes prior to cell lysis for Western blotting (A), 3-4 hours prior to RNA extraction and analysis by qPCR (B) or 7-8 hours prior to collection of conditioned media for analysis by ELISA or Western blotting (C, D). Shown in (A) is a representative immunoblot performed on cell lysate proteins (3 mice/experiment/condition) and (on the bottom) the ratios of pIGFIR:IGFIR based on 3 different experiments and normalized to $\beta$-actin that was used as a loading control. Shown in (B) are mean expression values of the indicated transcripts normalized to GAPDH and expressed as fold change relative to non-treated cells that were assigned a value of $1(n=3)$. Shown in (C) are results of ELISA and in (D) results of immunoblotting, both performed on conditioned media collected from cultured neutrophils. They are expressed as means of fold increase ( \pm SE) relative to unstimulated cells that were assigned a value of 1 . A representative immunoblot is shown in the inset (D). The values shown in the bar graph were normalized to $\beta$-actin levels in the total cell lysates obtained from the neutrophils that were used as source of conditioned media $(n=3) .{ }^{*} p<0.05$. 
polarization and thereby, a contributor to the prometastatic microenvironment of the liver.

Several studies have examined the role of IGF-I in the regulation of neutrophil function, with seemingly conflicting results. While Himpe et al. identified IGF-I as a survival factor for neutrophils, delaying their Fas -mediated apoptosis through the PI3K pathway [35], Zhao et al. have shown that IGF-I can inhibit neutrophil activation [36]. Pretreatment of neutrophils with IGF-I was also shown to suppress phagocytosis, but this function could be restored when they were co-stimulated with PMA or E. coli [37]. These studies identified IGF-IR as a player in the regulation of neutrophil function and suggested that the role it plays can vary, depending on the inflammatory context, assay conditions and the specific function analyzed.

The function of neutrophils in the context of tumor progression is complex, as they can exert both tumor promoting and tumor inhibitory effects. Our data suggest that within the unique microenvironment of the liver, neutrophils can enhance tumor expansion by releasing tumor-promoting molecules such as VEGF, thereby, potentially, contributing to neovascularization. Our data also implicate IGF in the regulation of this tumorpromoting function. The differences we have observed in the effects of short and longer-term IGF-I deficiencies on neutrophil functions and liver metastasis are consistent with our previous observations [22]. They are most likely related to the reduction in IGF-IR expression levels, under conditions of a more sustained IGF-I deficiency. Similar findings were reported in a study of Ewing's and osteogenic sarcoma xenografts following the exposure of the animals to an anti-IGF-IR antibody (AMG-479) for 3 weeks [38]. Recently, we documented a similar effect on hepatic stellate cells [23] that can also promote liver colonization by metastatic tumor cells. In both of these studies, reduced IGF-IR expression was observed on non-malignant cells exposed to lowered IGF-I levels for 3 weeks (but not

\section{A}
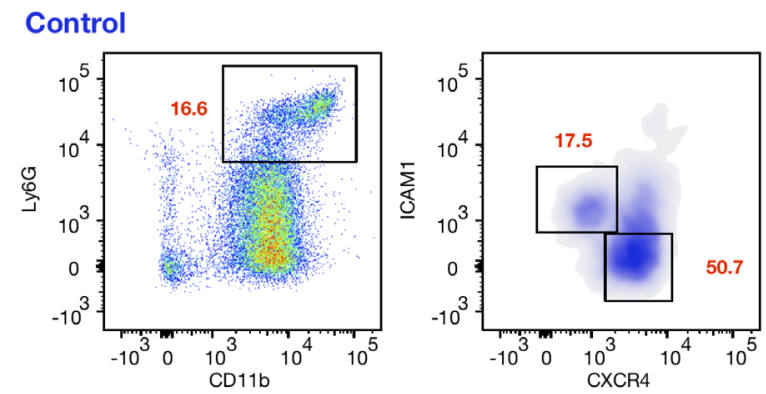

Trap $1 \mathrm{mg} / \mathrm{kg}$
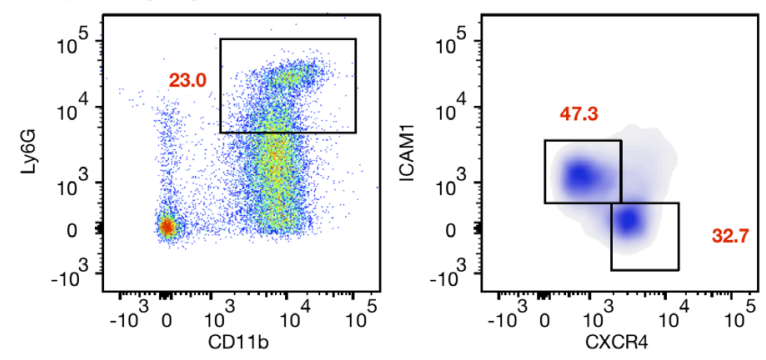

Trap $10 \mathrm{mg} / \mathrm{kg}$
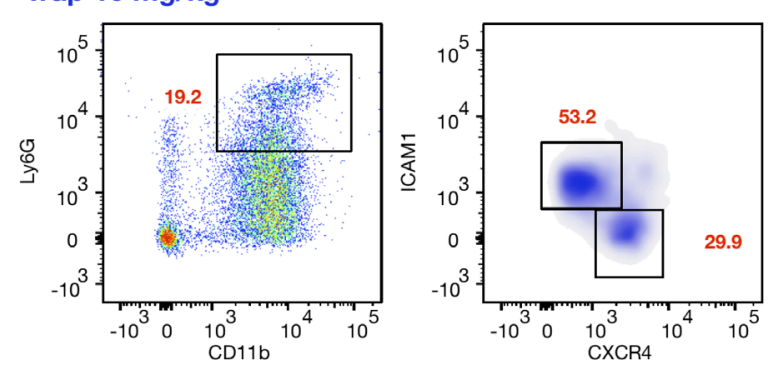

B

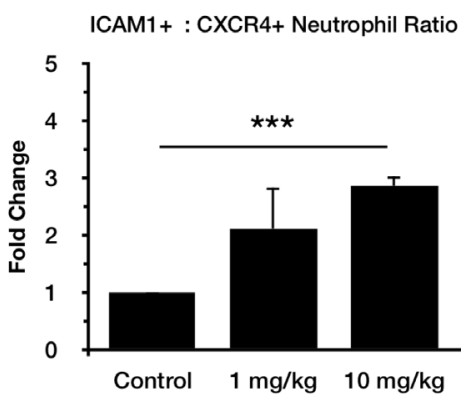

Figure 6: Treatment with the IGF-TRAP reduces the proportion of N2-polarized tumor-infiltrating neutrophils in vivo. $\mathrm{C} 57 \mathrm{Bl} / 6$ mice were injected with $2.5 \times 10^{5} \mathrm{MC}-38$ cells via the intrasplenic/portal route. Treatment with $1 \mathrm{or} 10 \mathrm{mg} / \mathrm{kg} \mathrm{IGF-TRAP}$ was initiated one day later and continued on alternate days for a total of 3 injections per mouse. Animals were euthanized and immune cells collected 6 days post tumor injection. Shown in (A) are representative flow cytometric profiles of CD11b ${ }^{+}$Ly6G ${ }^{\text {High }}$ neutrophils obtained from treated and untreated mice (3-6 mice per treatment arm, $n=3$ ). The percent ICAM- $1^{+}$or $\mathrm{CXCR} 4^{+}$neutrophils are indicated in red. Shown in (B) are the means of fold change in the ratios of ICAM-1 $1^{+}$CXCR $4^{+}$neutrophils relative to control, non-treated mice $( \pm \mathrm{SE})$ that were assigned a value of 1 , based on the 3 experiments. ${ }^{* * *} p<0.001$. 
for 2 days). Collectively the results suggest that under normal physiological conditions, IGF-I bioavailability may regulate IGF-IR expression levels on these cells. They also highlight the important role that IGF-I plays in regulating a pro-metastatic microenvironment in the liver. It should be noted however, that reciprocal communication between hepatic stellate cells and neutrophils has been documented under various inflammatory conditions [39-41]. It is therefore possible that the change in neutrophil polarization observed in $\operatorname{iLID}^{3 \mathrm{~W}}$ mice was due, at least partially, to the reduced hepatic stellate cell activation in these mice or conversely, that reduced neutrophil polarization contributed to decreased stellate cell activation.

Neutrophil and macrophage polarization were previously shown to be driven by TGF $\beta[3,6]$. We have shown here that IGF-I could directly induce expression of $\mathrm{N} 2$-assocaited transcripts in neutrophils in vitro and also increased the expression of TGF $\beta$ in these cells. It is possible therefore that in vivo, IGF-I plays a dual role in N2 polarization by directly activating transcription of $\mathrm{N} 2$-associated genes and, in addition, upregulating TGF $\beta$ production, thereby indirectly contributing to an autocrine activation loop.

We observed an increase in CXCL-1 expression in whole livers of ILID $^{3 \mathrm{~W}}$ mice within 3 days post tumor injection. CXCL-1 is a major neutrophil chemoattractant [42]. This may account for the observed increase in the accumulation of $\mathrm{Ly} 6 \mathrm{G}^{+}$cells around tumor micrometastases, 6 days post tumor injection. The failure of the recruited neutrophils to polarize could have, in turn, decreased the incidence of metastases because N1 neutrophils are tumoricidal [6]. The source of increased CXCL-1 production in iLID mice remains to be identified, but several cell types are known to produce this chemokine, including activated endothelial cells, macrophages, neutrophils and hepatic stellate cells $[39,43$, 44]. Our results suggest that IGF-I may suppress CXCL1 production in one or more of these cells or indirectly regulate CXCL-1 levels by suppressing the expression of upstream mediators. This is in line with other studies that identified IGF-I as a mediator of immunosuppression and in particular, an inhibitor of interferon- $\gamma[45]$ - a known inducer of CXCL-1[46].

Recent studies identified TAN as prognostic factors in several types of cancers, including colon carcinoma [47]. High neutrophil to lymphocyte ratios were also shown to predict a poor outcome following hepatic resection for CRC liver metastases [48]. This suggests that neutrophils infiltrating hepatic metastases may accelerate their growth. When viewed in this context, our results suggest that in addition to its direct effects on tumor cells [12], IGF-I can also promote tumor growth through its immunomodulatory effects on tumor-infiltrating neutrophils, thereby contributing to a pro-metastatic microenvironment in the liver and amplifying its tumor- growth promoting effect. Tumor- associated neutrophils have been documented at the primary and metastatic sites of different malignancies and their phenotypes could have profound effects on the type of adaptive immune response mounted [49-51]. Our findings may therefore have implications beyond the management of liver metastatic disease. Collectively, our results provide a rationale for the use of IGF-targeting strategies for the reprogramming of innate immune response cells from a tumor-promoting to a tumor-inhibiting phenotype, thereby enhancing their anti-cancer activity.

\section{MATERIALS AND METHODS}

\section{Cells}

The origin, properties and maintenance of murine colon adenocarcinoma MC-38 cells and Lewis lung carcinoma H-59 cells were previously described $[52,53]$. Both cell lines were derived from tumors that arose in C57B1/6 mice and were used here in the syngeneic strain. MC-38 cells were originally from an NCI repository and were obtained as a kind gift from Dr. Shoshana Yakar (New York University, NY) in 2005. They were recently authenticated by Didion and colleagues using SNP profiling, as described [54]. H-59 is a subline of the Lewis lung carcinoma that was developed by our laboratory in 1986, as described in detail previously [53]. These cells were maintained as a frozen stock and cultured for no longer than 4 weeks in DMEM (MC-38) or RPMI (H-59) media supplemented with $10 \%$ FBS and antibiotics, before the analyses described, in order to ensure the stability of their metastatic phenotypes. The cell lines were routinely tested for mouse pathogens and mycoplasma, as per the McGill University Animal Care committee guidelines and were last tested in 2016.

\section{Animals}

All mouse experiments were carried out in strict accordance with the recommendations of the Canadian Council on Animal Care (CCAC) "Guide to the Care and Use of Experimental Animals" and under the conditions and procedures approved by the Animal Care Committee of McGill University (AUP \# 5260). C57Bl/6 female mice were obtained from Charles River Laboratories (St. Constant, QC, Canada) and used for the experiments at the age of 7-10 wks. A colony of mice with an inducible, liver specific IGF-I deficiency (iLID) was maintained in the animal facility of the Research Institute of the McGill University Health Center, as per the guidelines of the McGill University Animal Care Committee. Newborn mice were routinely genotyped, as described in detail previously [23] and only female mice were used in this study. In these mice, a single TX injection results in gene recombination by activating the Cre recombinase 
gene under the control of a liver specific anti-trypsin $1 \alpha$ promoter. The inducible igfl deletion results in a 50 80\% reduction in serum IGF-I levels within $\sim 18 \mathrm{hr}$ of a single i.p. injection of $0.3 \mathrm{mg}$ TX per mouse (Supplementary Figure 3 ). We routinely confirmed reduced IGF-I plasma levels in all iLID mice prior to use in the experiments described (see Supplementary Table 1). Serum IGF-I levels were measure using the DuoSet IGF-I ELISA kit (R\&D) that quantifies unbound IGF-I levels.

\section{Antibodies and reagents}

The antibodies and reagents used are listed in Supplementary Table 2 .

\section{RNA extraction and $q R T-P C R$}

Total cellular RNA was extracted using Trizol (Life Technologies, Burlington, ON, Canada). RT-PCR was performed using the Moloney murine leukemia virus (MMLV) reverse transcriptase and Taq DNA polymerase (both from Invitrogen, Carlsbad, CA). qPCR was performed with the $\mathrm{iQ}^{\mathrm{TM}} \mathrm{SYBR}^{\circledR}$ Green Supermix (Bio-Rad Laboratories, Mississauga, ON, Canada) in a standard PCR mixture containing $0.5 \mu \mathrm{M}$ of each primer (all primers are listed in Supplementary Table 3), $3 \mathrm{mM}$ $\mathrm{MgCl}_{2}$, and $2 \mu \mathrm{g} \mathrm{cDNA}$. Amplification and detection were performed in a BioRad LightCycler instrument (Bio-Rad Laboratories) using $25 \mu 1$ reaction mixture and 40 cycles of denaturation $\left(95^{\circ} \mathrm{C}, 10 \mathrm{sec}\right)$ and annealing $\left(60^{\circ} \mathrm{C}, 30 \mathrm{sec}\right)$. A single fluorescence reading was taken at each extension step and the iQ5 software (Bio-Rad Laboratories) was used for data analysis.

\section{Protein extraction and Western blotting}

Total cell lysates were prepared as described in detail elsewhere [55]. Serum-free neutrophil conditioned media were collected and concentrated 20-fold using Amicon Ultra 3K Centrifugal devices (EMD Millipore, Etobicoke, Ontario, Canada). Cell lysate and conditioned media proteins were separated by polyacrylamide gel electrophoresis (PAGE) using 10\% SDS gels, and Western blotting performed as we previously described [55]. Primary and secondary antibody dilutions are indicated in Supplementary Table 2. The Amersham ECL Select Western Blotting Detection Reagent (GE Healthcare, Mississauga, ON, Canada) was used to detect the chemiluminescent signal.

\section{ELISA}

The Ray Bio $^{\odot}$ mouse Rantes (CCL5) ELISA kit (Ray Biotech inc, Norcross, GA) was used to measure levels of CCL5 in concentrated conditioned media and the DuoSet IGF-I ELISA kit (R\&D) for measuring serum IGF-I levels, as instructed by the manufacturer.

\section{Experimental metastasis assays}

Experimental liver metastases were generated by intrasplenic/portal injections of $2.5 \times 10^{4} \mathrm{MC}-38$ cells or $10^{5} \mathrm{H}-59$ cells followed by splenectomy, as previously described [56, 57]. The number of tumor cells to be injected was determined based on preliminary doseresponse analyses and selected to produce a quantifiable number of visible hepatic metastases within 14 (H-59) and 16 (MC-38) days post-tumor inoculation, at which time the animals were euthanized. Visible metastases on the surfaces of the livers were enumerated immediately after liver resection and prior to fixation.

\section{IHC and confocal microscopy}

Cryostat sections $(10 \mu \mathrm{m})$ were prepared from snap frozen liver fragments that were perfused with, and then fixed in a 4\% paraformaldehyde solution. The sections were incubated overnight with primary antibodies diluted as indicated (Supplementary Table 2) in blocking solution ( $1 \%$ BSA and $1 \%$ FBS in PBS) and then for 1 hour at RT with Alexa Fluor 647 goat anti-rabbit or Alexa Fluor 568 goat anti-rat antibodies (Molecular Probes, Invitrogen), as appropriate, diluted 1:200 and used in the presence of DAPI $(1: 2,000)$. The sections were washed and mounted with the GOLD anti-fade reagent (Invitrogen) and images analyzed with a Zeiss LSM 510 Meta or a Zeiss LSM 780, confocal microscope (Carl Zeiss Canada Ltd, Toronto, Ontario, Canada) equipped with a Zen image analysis station.

\section{Isolation and flow cytometry of hepatic immune cells and bone marrow neutrophils}

Hepatic immune cells were extracted using the protocol described in detail elsewhere [58]. Briefly, liver homogenates were prepared in cold PBS and filtered through a stainless-steel mesh using a plunger. The filtrate was centrifuged at $60 \mathrm{~g}$ to separate the hepatocytes, the supernatant containing the non-parenchymal fraction centrifuged at $480 \mathrm{~g}$ at RT and the pellet resuspended in $10 \mathrm{ml}$ of a $37.5 \%$ Percoll solution in HBSS containing $100 \mathrm{U} / \mathrm{ml}$ heparin and centrifuged at $850 \mathrm{~g}$ for $30 \mathrm{~min}$ at RT to obtain an immune cell-rich fraction. Bone marrow neutrophils were isolated as described in detail elsewhere [59]. Briefly, femurs of C57BL/6 female mice were collected, and the bone marrow flushed out with a HBSS prep (HBSS with $0.5 \%$ FBS and $20 \mathrm{mM}$ HEPES), using a $20 \mathrm{ml}$ syringe and a $22 \mathrm{G}$ needle. The pellet was broken up by pipetting, using a $20 \mathrm{ml}$ syringe and an $18 \mathrm{G}$ needle. Following centrifugation, the pellet containing the bone marrow was resuspended with $5 \mathrm{ml}$ HBSS prep and the 
cells layered on a $62 \%$ percoll solution and centrifuged to separate the neutrophils (in the pellet) from the interphase containing lymphocytes. For both procedures, neutrophils from 5-10 mice per experimental group were pooled in order to obtain adequate numbers for the analyses. Red blood cells were removed using the ACK lysing buffer prior to cell immunostaining with fluorescent-conjugated antibodies to the indicated cell surface markers and flow cytometry. Data acquisition was with a BD Canto flow cytometer and the FACsDiva software (San Jose, CA, USA) and data analysis with the FlowJo software (Ashland, OR, USA).

\section{Arginase assay}

Arginase activity was measured in cell lysates, using the Quantichrome Arginase Assay Kit (BioAssay Systems, Hayward, CA). CD11b Ly6G $^{+}$ cells were washed with $\mathrm{PBS}$ and centrifuged at $4^{\circ} \mathrm{C}$ for 10 minutes at $1,000 \mathrm{~g}$. The pellets were lysed in a $10 \mathrm{mM}$ Tris- $\mathrm{HCl}(\mathrm{pH}$ 7.4) buffer containing $0.4 \%$ Triton $\mathrm{X}-100,1 \mathrm{mM}$ pepstatin $\mathrm{A}$, and $1 \mathrm{mM}$ leupeptin and the cell lysates centrifuged at $4^{\circ} \mathrm{C}$ for 10 minutes at $14,000 \mathrm{~g}$ prior to measuring arginase activity, as per the manufacturer's instructions.

\section{Nitric oxide assay}

Nitric oxide activity in the conditioned media was measured using the Griess reagent system (Promega

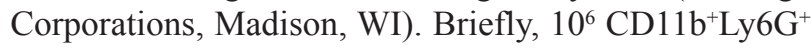
cells derived from $\mathrm{iLID}^{3 \mathrm{~W}}$ and control mice were plated in a 96 well-plate and incubated overnight at $37^{\circ} \mathrm{C}$. Conditioned media were then collected, cleared of cells by centrifugation at $1000 \mathrm{~g}$ for $5 \mathrm{~min}$ and analyzed for nitrite concentration as per the manufacturer's instructions.

\section{IGF-TRAP treatment}

$\mathrm{C} 57 \mathrm{Bl} / 6$ female mice were injected i.v. with 1 or 10 $\mathrm{mg} / \mathrm{kg}$ of the IGF-TRAP [26] (or saline for control) 1, 3 and 5 days following the intrasplenic/portal inoculation of $2.5 \times 10^{5} \mathrm{MC}-38$ cells. Livers were processed for RNA extraction and flow cytometry, 6 days post tumor inoculation.

\section{Statistical analysis}

All cell based data (in vitro assays and IHC) were analyzed by a one-tailed Student's $t$-test. The nonparametric Mann-Whitney test was used to analyze experimental metastasis data.

\section{Author contributions}

RFR-Contributed to the design of the experiments, performed most of the experiments, acquired and analyzed the data and contributed to manuscript preparation. SMperformed some of the experiments, analyzed the data and assisted in manuscript preparation. MCM and $\mathrm{BH}$ assisted in the performance of some of the experiments. NW, FB and SP - assisted in animal injections and surgery. SY-provided the iLID mice breeders, contributed to the design of the experiments and critically reviewed the manuscript. PB - Conceived, supervised and coordinated this study, supervised study design and data analysis, edited the manuscript.

\section{ACKNOWLEDGMENTS}

The authors would like to thank Dr Min Fu (Manager of the Molecular Imaging Facility at the MUHC RI) for help in the confocal microscopy as well as Ms. Camille Stegen (Manager of the flow cytometry and cell sorting facility at McGill University), Marie Helene Lacombe and Ekaterina Lourtchenko (Immunophenotyping Facility at the MUHC RI) for their help with flow cytometry.

\section{CONFLICTS OF INTEREST}

The authors have no conflict of interest to declare.

\section{FUNDING}

RFR was supported by a Henry R. Shibata fellowship from the Cedars Cancer Institute and by a Mathematics of Information Technology and Complex Systems (MITACS) internship. SM was supported by a M.Sc. training award from Fonds de Recherche du Québec-Santé (FRQS). MCF was supported by a Henry R. Shibata fellowship from the Cedars Cancer Institute, a McGill Integrated Cancer Research Training Program (MICRTP) internship and MITACS.

This study was supported by grants MOP-80201 from the Canadian Institute for Health Research and PSRSIIRI-843 from the Québec Ministère de l'Économie, de l'Innovation et des Exportations (to PB).

\section{REFERENCES}

1. Murray PJ, Allen JE, Biswas SK, Fisher EA, Gilroy DW, Goerdt S, Gordon S, Hamilton JA, Ivashkiv LB, Lawrence T, Locati M, Mantovani A, Martinez FO, et al. Macrophage activation and polarization: nomenclature and experimental guidelines. Immunity. 2014; 41:14-20.

2. Schouppe E, De Baetselier P, Van Ginderachter JA, Sarukhan A. Instruction of myeloid cells by the tumor microenvironment: Open questions on the dynamics and plasticity of different tumor-associated myeloid cell populations. OncoImmunology. 2012; 1:1135-1145. 
3. Mills CD, Kincaid K, Alt JM, Heilman MJ, Hill AM. M-1/ M-2 macrophages and the Th1/Th2 paradigm. J Immunol. 2000; 164:6166-6173.

4. Mantovani A, Sozzani S, Locati M, Allavena P, Sica A. Macrophage polarization: tumor-associated macrophages as a paradigm for polarized M2 mononuclear phagocytes. Trends Immunol. 2002; 23:549-555.

5. Martinez FO, Gordon S. The M1 and M2 paradigm of macrophage activation: time for reassessment. F1000prime Rep. 2014; 6:13.

6. Fridlender ZG, Sun J, Kim S, Kapoor V, Cheng G, Ling L, Worthen GS, Albelda SM. Polarization of tumor-associated neutrophil phenotype by TGF-beta: "N1" versus "N2" TAN. Cancer Cell. 2009; 16:183-194.

7. Bird L. Tumour immunology: Neutrophil plasticity. Nat Rev Immunol. 2009; 9:672-673.

8. Piccard H, Muschel RJ, Opdenakker G. On the dual roles and polarized phenotypes of neutrophils in tumor development and progression. Crit Rev Oncol Hematol. 2012; 82:296-309.

9. Seccareccia E, Brodt P. The role of the insulin-like growth factor-I receptor in malignancy: An update. Growth Horm IGF Res. 2012; 22:193-199.

10. Datta SR, Dudek H, Tao X, Masters S, Fu H, Gotoh Y, Greenberg ME. Akt phosphorylation of BAD couples survival signals to the cell-intrinsic death machinery. Cell. 1997; 91:231-241.

11. Parrizas M, Saltiel AR, LeRoith D. Insulin-like growth factor 1 inhibits apoptosis using the phosphatidylinositol 3'-kinase and mitogen-activated protein kinase pathways. J Biol Chem. 1997; 272:154-161.

12. Samani AA, Yakar S, LeRoith D, Brodt P. The role of the IGF system in cancer growth and metastasis: overview and recent insights. Endocr Rev. 2007; 28:20-47.

13. Heemskerk VH, Daemen MA, Buurman WA. Insulin-like growth factor-1 (IGF-1) and growth hormone (GH) in immunity and inflammation. Cytokine Growth Factor Rev. 1999; 10:5-14.

14. Stuart CA, Meehan RT, Neale LS, Cintron NM, Furlanetto RW. Insulin-like growth factor-I binds selectively to human peripheral blood monocytes and B-lymphocytes. J Clin Endocrinol Metab. 1991; 72:1117-1122.

15. Kooijman R, Willems M, De Haas CJ, Rijkers GT, Schuurmans AL, Van Buul-Offers SC, Heijnen CJ, Zegers BJ. Expression of type I insulin-like growth factor receptors on human peripheral blood mononuclear cells. Endocrinology. 1992; 131:2244-2250.

16. Badolato R, Bond HM, Valerio G, Petrella A, Morrone G, Waters MJ, Venuta S, Tenore A. Differential expression of surface membrane growth hormone receptor on human peripheral blood lymphocytes detected by dual fluorochrome flow cytometry. J Clin Endocrinol Metab. 1994; 79:984-990.
17. Knittel T, Dinter C, Kobold D, Neubauer K, Mehde M, Eichhorst S, Ramadori G. Expression and regulation of cell adhesion molecules by hepatic stellate cells (HSC) of rat liver: involvement of HSC in recruitment of inflammatory cells during hepatic tissue repair. Am J Pathol. 1999; 154:153-167.

18. Yakar S, Leroith D, Brodt P. The role of the growth hormone/insulin-like growth factor axis in tumor growth and progression: Lessons from animal models. Cytokine Growth Factor Rev. 2005; 16:407-420.

19. Moody G, Beltran PJ, Mitchell P, Cajulis E, Chung YA, Hwang D, Kendall R, Radinsky R, Cohen P, Calzone FJ. IGF1R blockade with ganitumab results in systemic effects on the GH-IGF axis in mice. J Endocrinol. 2014; 221:145-155.

20. Welniak LA, Karas M, Yakar S, Anver MR, Murphy WJ, LeRoith D. Effects of organ-specific loss of insulin-like growth factor-I production on murine hematopoiesis. Biol Blood Marrow Transplant. 2004; 10:32-39.

21. Durfort T, Tkach M, Meschaninova MI, Rivas MA, Elizalde PV, Venyaminova AG, Schillaci R, Francois JC. Small interfering RNA targeted to IGF-IR delays tumor growth and induces proinflammatory cytokines in a mouse breast cancer model. PLoS One. 2012; 7:e29213.

22. Wu Y, Brodt P, Sun H, Mejia W, Novosyadlyy R, Nunez N, Chen X, Mendoza A, Hong SH, Khanna C, Yakar S. Insulinlike growth factor-I regulates the liver microenvironment in obese mice and promotes liver metastasis. Cancer Res. 2010; 70:57-67.

23. Fernandez MC, Rayes R, Ham B, Wang N, Bourdeau F, Milette S, Lllemann M, Bird N, Majeed A, Xu J, Kisselova T, Brodt P. The type I Insulin-like growth factor regulates the liver stromal response to metastatic colon carcinoma cells. Oncotarget. 2017; 8:52281-52293. https://doi.org/10.18632/ oncotarget.12595.

24. Lu B, Chen HD, Lu HC. The relationship between apoptosis and aging. Adv Biosci Biotechnol. 2012; 3:705-711.

25. Belfiore A, Goldfine I. R M. IGF-I and Insulin Receptor Families in Cancer. In: Fantus I, editor. Insulin Resistance and Cancer. New York (N Y): Springer; 2011. https://doi. org/10.1007/978-1-4419-9911-5_11.

26. Wang N, Rayes RF, Elahi SM, Lu Y, Hancock MA, Massie B, Rowe GE, Aomari H, Hossain S, Durocher Y, Pinard M, Tabariès S, Siegel PM, Brodt P. The IGF-Trap: Novel Inhibitor of Carcinoma Growth and Metastasis. Mol Cancer Ther. 2015; 14:982-93.

27. Zhang D, Samani AA, Brodt P. The role of the IGF-I receptor in the regulation of matrix metalloproteinases, tumor invasion and metastasis. Horm Metab Res. 2003; 35:802-808.

28. Smith TJ. Insulin-like growth factor-I regulation of immune function: a potential therapeutic target in autoimmune diseases? Pharmacol Rev. 2010; 62:199-236.

29. Alami N, Page V, Yu Q, Jerome L, Paterson J, Shiry L, Leyland-Jones B. Recombinant human insulin-like growth 
factor-binding protein 3 inhibits tumor growth and targets the Akt pathway in lung and colon cancer models. Growth Horm IGF Res. 2008; 18:487-496.

30. Friedbichler K, Hofmann MH, Kroez M, Ostermann E, Lamche HR, Koessl C, Borges E, Pollak MN, Adolf G, Adam PJ. Pharmacodynamic and antineoplastic activity of BI 836845, a fully human IGF ligand-neutralizing antibody, and mechanistic rationale for combination with rapamycin. Mol Cancer Ther. 2014; 13:399-409.

31. Gao J, Chesebrough JW, Cartlidge SA, Ricketts SA, Incognito L, Veldman-Jones M, Blakey DC, Tabrizi M, Jallal B, Trail PA, Coats S, Bosslet K, Chang YS. Dual IGF-I/II-neutralizing antibody MEDI-573 potently inhibits IGF signaling and tumor growth. Cancer Res. 2011; 71:1029-1040.

32. Sachdev D. Drug evaluation: CP-751871, a human antibody against type I insulin-like growth factor receptor for the potential treatment of cancer. Curr Opin Mol Ther. 2007; 9:299-304.

33. Sachdev D, Singh R, Fujita-Yamaguchi Y, Yee D. Downregulation of insulin receptor by antibodies against the type I insulin-like growth factor receptor: implications for antiinsulin-like growth factor therapy in breast cancer. Cancer Res. 2006; 66:2391-2402.

34. Van den Berg CL, Cox GN, Stroh CA, Hilsenbeck SG, Weng CN, McDermott MJ, Pratt D, Osborne CK, Coronado-Heinsohn EB, Yee D. Polyethylene glycol conjugated insulin-like growth factor binding protein-1 (IGFBP-1) inhibits growth of breast cancer in athymic mice. Eur J Cancer. 1997; 33:1108-1113.

35. Himpe E, Degaillier C, Coppens A, Kooijman R. Insulinlike growth factor-1 delays Fas-mediated apoptosis in human neutrophils through the phosphatidylinositol-3 kinase pathway. J Endocrinol. 2008; 199:69-80.

36. Zhao J, Harada N, Sobue K, Katsuya H, Okajima K. Insulin-like growth factor-I reduces stress-induced gastric mucosal injury by inhibiting neutrophil activation in mice. Growth Horm IGF Res. 2009; 19:136-45.

37. Balteskard L, Unneberg K, Halvorsen D, Hansen JB, Revhaug A. Effects of insulin-like growth factor 1 on neutrophil and monocyte functions in normal and septic states. JPEN J Parenter Enteral Nutr. 1998; 22:127-35.

38. Beltran PJ, Chung YA, Moody G, Mitchell P, Cajulis E, Vonderfecht S, Kendall R, Radinsky R, Calzone FJ. Efficacy of ganitumab (AMG 479), alone and in combination with rapamycin, in Ewing's and osteogenic sarcoma models. J Pharmacol Exp Ther. 2011; 337:644-654.

39. Bigorgne AE, John B, Ebrahimkhani MR, ShimizuAlbergine M, Campbell JS, Crispe IN. TLR4-Dependent Secretion by Hepatic Stellate Cells of the NeutrophilChemoattractant CXCL1 Mediates Liver Response to Gut Microbiota. PLoS One. 2016; 11:e0151063.

40. Heymann F, Tacke F. Immunology in the liver-from homeostasis to disease. Nat Rev Gastroenterol Hepatol. 2016; 13:88-110.
41. Koyama Y, Brenner DA. Liver inflammation and fibrosis. J Clin Invest. 2017; 127:55-64.

42. Moser B, Clark-Lewis I, Zwahlen R, Baggiolini M. Neutrophil-activating properties of the melanoma growthstimulatory activity. J Exp Med. 1990; 171:1797-1802.

43. Iida N, Grotendorst GR. Cloning and sequencing of a new gro transcript from activated human monocytes: expression in leukocytes and wound tissue. Mol Cell Biol. 1990; 10:5596-5599.

44. Becker S, Quay J, Koren HS, Haskill JS. Constitutive and stimulated MCP-1, GRO alpha, beta, and gamma expression in human airway epithelium and bronchoalveolar macrophages. Am J Physiol. 1994; 266:L278-286.

45. Puzik A, Rupp J, Tröger B, Göpel W, Herting E, Härtel C. Insulin-like growth factor-I regulates the neonatal immune response in infection and maturation by suppression of IFN- $\gamma$. Cytokine. 2012; 60:369-376.

46. Glineur SF, Bowen AB, Percopo CM, Garcia-Crespo KE, Dyer KD, Ochkur SI, Lee NA, Lee JJ, Domachowske JB, Rosenberg HF. Sustained inflammation and differential expression of interferons type I and III in PVM-infected interferon-gamma (IFN $\gamma$ ) gene-deleted mice. Virology. 2014; 468-470:140-149.

47. Donskov F. Immunomonitoring and prognostic relevance of neutrophils in clinical trials. Semin Cancer Biol. 2013; 23:200-207.

48. Halazun KJ, Aldoori A, Malik HZ, Al-Mukhtar A, Prasad KR, Toogood GJ, Lodge JP. Elevated preoperative neutrophil to lymphocyte ratio predicts survival following hepatic resection for colorectal liver metastases. Eur J Surg Oncol. 2008; 34:55-60.

49. Gregory AD, Houghton AM. Tumor-associated neutrophils: new targets for cancer therapy. Cancer Res. 2011; 71:2411-2416.

50. Shen M, Hu P, Donskov F, Wang G, Liu Q, Du J. Tumorassociated neutrophils as a new prognostic factor in cancer: a systematic review and metaanalysis. PLoS One. 2014; 9:e98259.

51. Tuting $\mathrm{T}$, de Visser KE. CANCER. How neutrophils promote metastasis. Science. 2016; 352:145-146.

52. Wang N, Fallavollita L, Nguyen L, Burnier J, Rafei M, Galipeau J, Yakar S, Brodt P. Autologous bone marrow stromal cells genetically engineered to secrete an igf-I receptor decoy prevent the growth of liver metastases. Mol Ther. 2009; 17:1241-1249.

53. Brodt P. Characterization of two highly metastatic variants of Lewis lung carcinoma with different organ specificities. Cancer Res. 1986; 46:2442-2448.

54. Didion JP, Buus RJ, Naghashfar Z, Threadgill DW, Morse HC 3rd, de Villena FP. SNP array profiling of mouse cell lines identifies their strains of origin and reveals crosscontamination and widespread aneuploidy. BMC Genomics. $2014 ; 15: 847$. 
55. Zhang D, Brodt P. Type 1 insulin-like growth factor regulates MT1-MMP synthesis and tumor invasion via PI 3-kinase/Akt signaling. Oncogene. 2003; 22:974-982.

56. Brodt P, Fallavollita L, Khatib AM, Samani AA, Zhang D. Cooperative regulation of the invasive and metastatic phenotypes by different domains of the type I insulin-like growth factor receptor beta subunit. J Biol Chem. 2001; 276:33608-33615.

57. Samani AA, Chevet E, Fallavollita L, Galipeau J, Brodt P. Loss of tumorigenicity and metastatic potential in carcinoma cells expressing the extracellular domain of the type 1 insulin-like growth factor receptor. Cancer Res. 2004; 64:3380-3385.

58. Blom KG, Qazi MR, Matos JB, Nelson BD, DePierre JW, Abedi-Valugerdi M. Isolation of murine intrahepatic immune cells employing a modified procedure for mechanical disruption and functional characterization of the B, $\mathrm{T}$ and natural killer T cells obtained. Clin Exp Immunol. 2009; 155:320-329.

59. Swamydas M, Lionakis MS. Isolation, purification and labeling of mouse bone marrow neutrophils for functional studies and adoptive transfer experiments. J Vis Exp. 2013:e50586. 